\title{
TEOLOGI DEVOSI MARIAWI MENURUT LOUIS-MARIE GRIGNION DE MONTFORT DAN PENGARUHNYA PADA SPIRITUALITAS KATOLIK: SEBUAH TINJAUAN KRITIS DARI PERSPEKTIF REFORMED
}

\author{
Nathanael Marvin Santino \\ Gereja Reformed Injili Indonesia Semarang \\ Korespondensi: nathanaelmarvin@yahoo.com \\ Diajukan: 20-Agt-2017; Direview: 26-Sep-2017; Diterima: 13-Okt-2017; Direvisi: 18-Okt-2017
}

\begin{abstract}
ABSTRAK: Dasar teologi devosi Mariawi yang dikembangkan oleh Louis-Marie Grignion de Montfort adalah kecintaannya pada Maria yang diperoleh melalui pengajaran Alkitab, tradisi gereja katolik, dan Magisterium gereja Katolik mengenai Mariologi. Signifikansi yang diberikan teologi ini terhadap spiritualitas umat Katolik yaitu sudut pandang baru untuk mengkhususkan hidup secara total kepada Yesus melalui Maria dan pendekatan devosi yang menyatakan bahwa Yesus dan Maria tidak terpisahkan. Akibat ajaran dan karya Montfort ini, muncul semangat yang baru dalam devosi kepada Maria sehingga muncul kongregasi-kongregasi baru di dalam spiritualitas Mariawi. Kongregasi-kongregasi yang berdiri akibat ajaran Montfort adalah Company of Mary, Daughters of Wisdom, dan Brothers of Saint Gabriel. Studi ini membuktikan bahwa menurut sudut pandang teologi Reformed, teologi devosi Mariawi ini bukanlah ajaran yang berdasarkan Alkitab. Alkitab mengajarkan devosi umat hanya kepada Allah Tritunggal di dalam dan melalui Kristus tanpa perlu pengantara yang lain.
\end{abstract}

KATA KUNCI: Mariologi; Maria; Devosi Mariawi; Spiritualitas; Montfort; Katolik.

ABSTRACT: Marian devotional theology which was developed by Louis-Marie Grignion de Montfort is based on his love towards Mary that 
he gained through the teaching of the Bible, the tradition of the Catholic church, and the Magisterium of the Catholic church on Mariology. The significant of this theology for Catholic spirituality is a new point of view to consecrate life totally to Jesus through Mary and a devotional approach that perceives Jesus and Mary are inseparable. As a result of Montfort's teachings and works, a new spirit emerged in devotion to Mary that new congregations emerged within Marian spirituality. These congregations are the Company of Mary, Daughters of Wisdom, and the Brothers of Saint Gabriel. This study proves that according to reformed theology, Marian devotional theology is not a biblical doctrine. The Bible teaches that human devotion only to the Triune God in and through Christ without another mediator.

KEYWORDS: Mariology; Mary; Marian Devotion; Spirituality; Montfort; Catholic.

\section{Pendahuluan}

Doktrin Mariologi adalah studi yang membahas kehidupan, peran, dan kebajikan Maria, ibu Yesus Kristus. ${ }^{1}$ Kisah kehidupan Maria bersumber dari Kitab Injil yang menjelaskan bagaimana Maria menaati panggilan Allah untuk menjadi Ibu Yesus Kristus di dunia. Oleh karena peran yang begitu unik dan sangat penting dalam sejarah keselamatan umat Tuhan, Maria menjadi tokoh yang sangat dihormati oleh orang orang Kristen. Pada abad ke-2, mulai muncul lukisan seorang perawan dan seorang anak di sebuah katakombe di Roma. ${ }^{2}$ Bahkan, devosi $^{3}$ kepada Maria telah menjadi pusat dalam seni dan spiritualitas tradisi Gereja Katolik dan Ortodoks. ${ }^{4}$ Maria seringkali diberi gelar Bunda Allah

\footnotetext{
1 Robert C. Broderick, ed., Catholic Encyclopedia, Reprint ed. (Nashville: Thomas Nelson, 1990), 370.

2 John R. Shinners, "The Cult of Mary and Popular Belief," dalam Mary, Woman of Nazareth (New York: Paulist Press, 1989), 163.

3 Dalam bahasa asketis, devosi menandakan pengabdian/ semangat/ afeksi terhadap halhal yang berkaitan dengan Allah. Dalam karya tulis ini penulis memakai definisi dari bahasa Latin, yaitu hormat, bakti, membaktikan diri atau penyerahan diri.

4 Kathleen Coyle, Mary in the Christian Tradition: From a Contemporary Perspective (England:
} 
Yang Diberkati (Blessed Mother of God) dikarenakan statusnya sebagai Ibu Yesus dan juga karena ketaatannya di dalam menerima perintah Allah sebagai Bunda Allah. Sebutan ini pertama kali muncul dalam Lukas 1:43 yang berkata "Siapakah aku ini sampai ibu Tuhan-ku datang mengunjungi $a k u$ ?" Doktrin Mariologi ini merupakan salah satu doktrin yang menjadi polemik di dalam sejarah kekristenan. Di satu sisi, Mariologi berkembang menjadi sebuah devosi kepada Maria kemudian menghasilkan pengajaran mengenai Maria yang beragam. Di sisi lain, beberapa kelompok orang khususnya orang-orang Kristen setelah Reformasi, menolak adanya ajaran maupun praktek devosi kepada Maria. Namun di tengah-tengah pro dan kontra ini, tema mengenai devosi Mariawi mengalami perkembangan yang progresif dari tahun ke tahun dan terus dipraktekkan oleh gereja Katolik. Mulai sejak gereja mula-mula, keputusan konsili - konsili gereja, sampai akhirnya Katolik mengakui devosi kepada Maria dalam Magisterium gereja Katolik. ${ }^{5}$

Praktek devosi kepada Maria mulai berkembang dan terjadi banyak hal mistis dan supranatural tentang Maria. Maria dianggap sebagai Bunda Ilahi dan mampu berelasi dengan umat manusia di zaman sekarang. Contohnya, ada seorang Roma Katolik di chapel Bosnia dan Herzegovina, dalam pedesaan Medjugorje, bernama Ivan Dragicevic berjalan lalu berlutut di altar, dan kemudian dia mulai berbisik, mendengarkan, dan tidak berkedip selama 10 menit. Hal yang dilakukan pemuda ini adalah berbicara dengan Bunda Maria. Bukan hanya bicara, tetapi melihat sebuah penglihatan Bunda Maria pada tahun 1981 bersama dengan 5 anak lainnya. Dikatakan bahwa Bunda Maria memperkenalkan dirinya sebagai "Ratu Damai" dan memberikan ribuan pesan kepada orang beriman untuk berdoa lebih sering dan meminta agar para pendosa bertobat. ${ }^{6}$

\footnotetext{
Gracewing, 1996), 1.

5 Contoh hasil Magisterium adalah ensiklik-ensiklik yang dikeluarkan Paus Katolik mengenai Mariologi. Misalnya Ensiklik Ineffabilis Deus, Muntificentissimus Deus, dan Marialis Cultus.

6 Maureen Orth, "Mary, The Most Powerful Woman in the World," dalam National
} 


\section{Sejarah Mariologi}

Pada abad ke-3, muncul sebuah penyembahan dalam ibadah Kristen pada Maria pertama kali yaitu melalui sebuah pujian Kristen dengan judul "Di bawah Perlindunganmu”. Isi pujiannya "Santa Maria, bunda Kristus kami berlindung padamu. Janganlah mengabaikan doa kami bila dirundung nestapa. Bebaskanlah kami selalu dari segala mara bahaya, ya perawan yang terpuji."7 Kemudian pada abad ke-5, tahun 431, Konsili Efesus menyatakan secara resmi bahwa Maria adalah Mother of God, atau dalam tradisi bahasa Yunani disebut Theotokos. ${ }^{8}$ Latar belakangnya berasal dari seorang Uskup Konstantinopel bernama Nestorius yang menyangkal doktrin inkarnasi (Yesus sepenuhnya Allah dan sepenuhnya manusia). Dia menganggap bahwa ketika Firman menjelma menjadi Yesus, Yesus benar-benar sepenuhnya menjadi manusia. Meskipun Nestorius percaya di dalam Yesus ada 2 sifat yaitu ilahi dan manusia, tetapi baginya kedua sifat itu masing-masing memiliki manifestasi sendiri. Oleh karena itu, Konsili Efesus menekankan betapa pentingnya pembedaan 2 natur Kristus yang disatukan dalam satu pribadi. Untuk membela doktrin dua natur Kristus ini, maka Maria disebut sebagai Bunda Allah sebagai pernyataan bahwa Yesus adalah Allah. Pernyataan Konsili ini:

We confess therefore our Lord Jesus Christ, the only begotten Son of God, perfect God and perfect human being composed of rational soul and body, begotten before all ages from the Father as to his divinity, and the same in the last days born of the Virgin Mary as to his humanity for us and for our salvation, consubstantial with the Father in divinity and consubstantial with us in humanity. For a union of two natures has taken place; hence we confess one Christ, one Son, one Lord. In accordance with this union without confusion, we confess the holy Virgin to be Mother of God (theotokos), for God the Word became flesh and was made human and

Geographic, December 2015, 34.

7 Louis-Marie Grignion de Montfort, Bakti Sejati Kepada Maria (Bandung: Serikat Maria Montfortan, 2000), 187. Kutipan Latin: “Sub tuum praesidium confugimus sancta Dei genitrix. Nostras deprecations, ne despicias in necessitatibus. Sed a periculis cunctis, libera nos semper, virgo gloriosa et benedicta."

8 Aidan Nichols, There Is No Rose: The Mariology of the Catholic Church (Minneapolis: Fortress Press, 2015), 10. 
from the moment of conception united to himself the temple he had taken from her. ${ }^{9}$

Sejak Konsili Efesus ini, Maria mulai dianggap sebagai wanita yang tiada duanya. Konsili ini menjadi pendorong umat untuk melakukan pembelajaran dan pemujaan kepada Maria. Maria dianggap sebagai simbol cinta kasih ibu, pengorbanan dan penderitaan. Bukan hanya itu, Maria seringkali dijadikan sebagai sebuah lambang kerinduan akan makna dan menjadi sebuah relasi yang lebih supranatural daripada menjadi pengajaran formal gereja. ${ }^{10}$ Maria juga sering dikaitkan sebagai pemberi perlindungan dan keamanan. Bahkan, Paus Fransiskus (Masa Jabatan: 2013 - Sekarang) memiliki pandangan terhadap Maria bahwa Maria adalah Ibunya (dalam arti spiritual). ${ }^{11}$

Berbagai macam doktrin mulai berkembang mengenai Maria sampai pada abad ke-21 ini. Beberapa doktrin penting yang dinyatakan oleh berbagai Paus dalam Ensiklik Roma Katolik mengenai Maria sebagai dogma gereja Katolik adalah doktrin Bunda Allah secara ilahi, artinya Maria memiliki peran ilahi di dalam penebusan umat manusia. Kedua, doktrin 'Konsepsi Tanpa Noda' yang mengajarkan bahwa ketika Maria di kandungan ibunya, dia tidak memiliki dosa asal karena sudah terlindung oleh anugerah. Ketiga, doktrin Perawan Selamanya yang mengajarkan baik sebelum, pada saat, dan sesudah melahirkan Yesus,

9 Richard P. McBrien, Catholicism (Minneapolis: Winston Press 1981), 452-453. Terjemahan: “Oleh karena itu kita mengaku Tuhan kita Yesus Kristus, Anak Tunggal Allah, Allah yang sempurna dan manusia yang sempurna yang terdiri dari tubuh dan jiwa yang rasional, diperanakkan sebelum segala zaman dari Allah Bapa untuk keilahian-Nya, dan yang sama di hari-hari terakhir kelahiran dari Perawan Maria untuk kemanusiaan-Nya, bagi kita dan keselamatan kita; sehakikat dengan Allah Bapa dalam keilahian dan sehakikat dengan kita dalam kemanusiaan. Karena persatuan dua kodrat telah terjadi; maka kita mengaku satu Kristus, satu Anak, satu Tuhan. Sesuai dengan persatuan tanpa kebingungan ini, kita mengaku Perawan suci untuk menjadi Bunda Allah (theotokos), sebab Allah Firman menjadi manusia, dan dibuat menjadi manusia dan dari saat konsepsi disatukan kepada diri-Nya sebuah kuil yang telah diambil dari Maria."

10 Maureen Orth, "Mary, The Most Powerful Woman in the World," National Geographic, December 2015, 36.

11 Ibid. 
Maria tetap Perawan. Keempat, doktrin Tubuh dan Jiwa Maria diangkat ke Surga.

Selanjutnya muncul sebuah doktrin bahwa Maria sebagai Pengantara umat kepada Yesus (Co-Mediatrix). Ide ini berasal dari kisah Yesus dan Maria di Kana. Pada saat itu Maria berbicara kepada Yesus bahwa mereka kehabisan anggur. Dengan segera Yesus melakukan mukjizat mengubah air menjadi anggur. John A. Hardon mengatakan Yesus melakukan mukjizat itu untuk memanifestasikan kemuliaan-Nya di dunia, dan menguatkan iman para murid-Nya (Yohanes 2:11). Menurut Hardon, jelas bahwa mukjizat yang dilakukan Yesus merupakan simpati hangat dari anak terhadap hasrat ibunya. ${ }^{12}$ Yang menggerakkan Yesus untuk melakukan mukjizat adalah Maria, bukan dari kehendak atau inisiatif Yesus sendiri. Seolah-olah tanpa permohonan Maria, Yesus tidak akan melakukan mukjizat. Atas dasar ini, Maria dapat menjadi seorang pengantara yang berdoa kepada Yesus, agar Yesus melakukan sesuatu. Sehingga dari hal ini terlihat bahwa Maria memiliki otoritas yang lebih besar dari Yesus Kristus. Hal ini menimbulkan praktek orang-orang percaya zaman sekarang untuk memanjatkan doa-doa kepada Maria sebagai pengantara agar doa mereka dikabulkan oleh Yesus Kristus. Berikut contoh doa kepada Maria yang begitu terkenal dengan sebutan Salam Maria/ Ave Maria,

Hail, Mary, full of grace, the Lord is with thee. Blessed art thou amongst women, and blessed is the fruit of thy womb, Jesus. Holy Mary, mother of God, pray for us sinners now and at the hour of our death. Amen. ${ }^{13}$

Kalimat ini diucapkan oleh jutaan umat Roma Katolik, dirangkum di dalam elemen paling mengejutkan dalam teka-teki Roma Katolik

\footnotetext{
12 John A. Hardon, The Catholic Catechism (New York: Doubleday, 1975), 150.

13 Jaroslav Pelikan. The Riddle of Roman Catholicism. (New York: Abingdon Press, 1952), 128. Terjemahan: Salam Maria, penuh rahmat, Tuhan sertamu, terpujilah engkau di antara wanita, dan terpujilah buah tubuhmu, Yesus. Santa Maria, Bunda Allah, doakanlah kami yang berdosa ini sekarang dan waktu kami mati. Amin.
} 
terhadap ritual doa dan devosi yang ditujukan pada Perawan Maria Yang Diberkati (Blessed Virgin Mary). ${ }^{14}$

Doktrin lainnya adalah bagaimana Maria memperoleh jabatan sebagai orang yang berperan di dalam sejarah penebusan dosa (CoRedemptrix). Peran Maria dalam penebusan dinyatakan di dalam satu kalimat:

The Blessed Virgin advanced in her pilgrimage of faith, and faithfully preserved in her union with her Son unto the cross, where she stood, in keeping with the divine plan, grieving exceedingly with her only-begotten Son, uniting herself with a maternal heart with his sacrifice, and lovingly consenting to the immolation of this victim, which she herself had brought forth. ${ }^{15}$

Hardon berpendapat bahwa gelar yang dimiliki Maria ini terletak pada kesakitan yang dia jalani dalam kesatuan dengan Anaknya. Dosa-dosa manusia diselesaikan dalam penderitaan Allah-Manusia, dan Yesus berharap ibu-Nya untuk berbagian dalam penderitaan itu sebagai orang yang paling Yesus cintai. ${ }^{16}$

\section{Devosi Mariawi}

Devosi berasal dari bahasa Latin yaitu devotio, yang berarti hormat, bakti, membaktikan diri atau penyerahan diri. ${ }^{17}$ Devosi merupakan sikap batin/ hati seseorang yang ditujukan kepada orang tertentu yang dia hormati, dia cintai, atau yang dia percayai. Lalu, devosi menurut dokumen Congregation for Divine Worship Vatikan 2 adalah:

Dalam konteks sekarang, istilah devosi digunakan untuk menggambarkan praktek eksternal (doa-doa, lagu-lagu pujian, pelaksanaan suatu kegiatan rohani yang berkaitan dengan waktu- waktu atau tempat - tempat tertentu,

\footnotetext{
14 Ibid.

15 Hardon, The Catholic Catechism, 168-169. Terjemahan: Perawan Terberkati berkembang dalam ziarah iman, dan dengan setia dipelihara dalam persatuannya dengan Putranya dalam salib, di mana ia berdiri, sesuai dengan rencana ilahi berduka sangat dengan Putra tunggalnya, menyatukan dirinya dengan hati dan pengorbanan seorang ibu, dan dengan penuh kasih menyetujui persembahan korban yang dia lahirkan.

16 Ibid.

17 Laurensius Dihe Sanga, Merenung Bersama Bunda Maria (Yogyakarta: Kanisius, 2014), 43.
} 
lencana, medali, kebiasaan- kebiasaan). Dihidupkan oleh sikap iman, praktek- praktek tersebut menyatakan hubungan yang khusus antara umat beriman dengan Pribadi Allah [Allah Bapa, Putera dan Roh Kudus] atau kepada Perawan Maria yang diberkati, dalam hak- hak istimewanya tentang rahmat dan segala sebutannya yang mengekspresikan keistimewaan tersebut, atau dengan para Santo/a di dalam konfigurasi mereka dengan Kristus atau di dalam peran mereka di dalam kehidupan Gereja. ${ }^{18}$

Menurut Pohle, devosi ini selalu terdiri dari tiga hal tindakan yang berbeda dan terpisah. Pertama, sebuah tindakan persetujuan intelektual untuk keagungan seseorang, ide atau objek yang merupakan objek penyembahan. Kedua, sebuah tindakan kehendak dimana penilaian teoritis menjadi praktis. Ketiga, sebuah tindakan eksternal dalam memberikan ekspresi kepada perasaan internal. ${ }^{19}$

Gereja Katolik membedakan objek devosi/ penyembahan yang dilakukan oleh umat. Pertama, penyembahan yang absolut kepada Allah Bapa, Yesus Kristus, dan Roh Kudus disebut Latria, yaitu sebuah penyembahan ilahi. Bila penyembahan ini dilakukan kepada makhluk hidup lain selain Allah, maka disebut penyembahan berhala. Kedua, penyembahan yang dilakukan kepada orang - orang kudus dan para malaikat, disebut Dulia. Ketiga, sebuah bentuk tertinggi dari Dulia yaitu Hyperdulia, penyembahan yang hanya dilakukan kepada Perawan Maria Yang Diberkati. Penyembahan ini lebih penting dari makhluk lain karena keunikannya sebagai Bunda Allah. ${ }^{20}$ Penulis membuat diagram tingkatan devosi di dalam umat Katolik sebagai berikut:

\footnotetext{
18 http://www.katolisitas.org.

19 Joseph Pohle, A Dogmatic Treatise On The Blessed Virgin Mary, Mother of God (London:

B.Herder, 1914), 132.

20 Ibid., 134.
} 


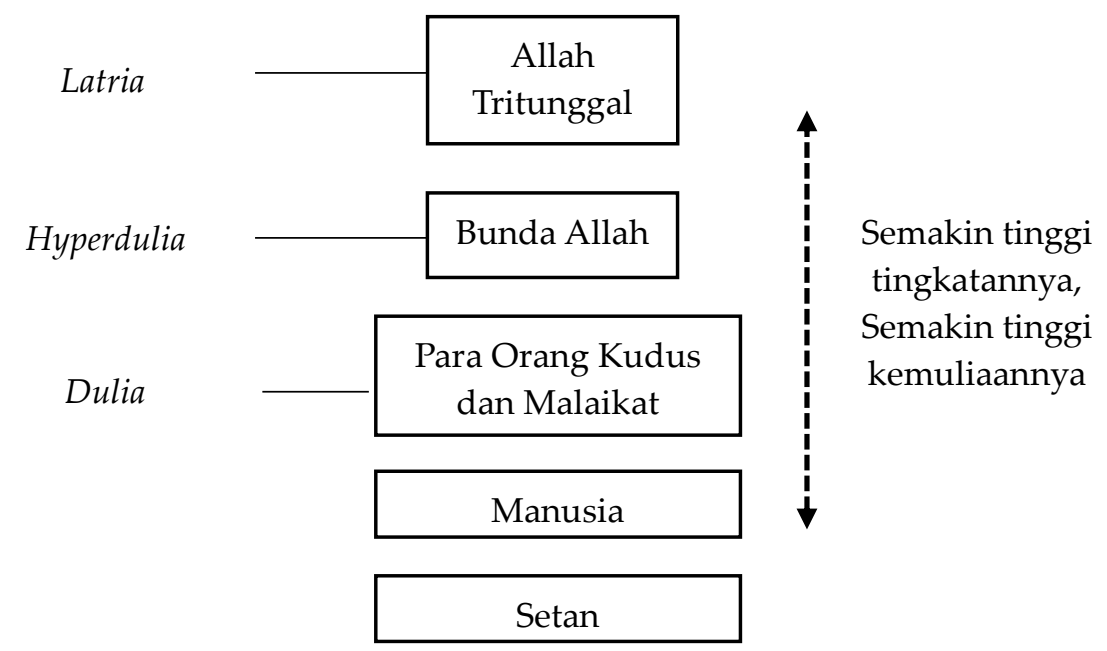

Sebagai konsekuensinya, Gereja Katolik menganggap Maria merupakan pribadi yang secara esensial di bawah Allah dan melebihi Para Orang Kudus dan Malakat. Maria bukanlah Pencipta/ Allah, tetapi dia adalah ciptaan yang memiliki kemuliaan melebihi segala ciptaan lainnya.

\section{Teologi Devosi Mariawi Menurut Montfort}

Pada abad 17, seorang teolog spiritualitas Roma Katolik Perancis bernama Louis-Marie Grignion de Montfort memberi perkembangan besar dalam pengajaran Roma Katolik mengenai devosi Mariawi. Dia mengajarkan bahwa seseorang harus mengonsekrasikan ${ }^{21}$ hidupnya kepada Maria dan bagaimana seseorang melakukan devosi kepada Yesus melalui Maria. Dia mengatakan bahwa konsekrasi kepada Maria ini "Terdiri dari penyerahan diri dalam cara sebagai budak kepada Maria, dan kepada Yesus melalui dirinya, dan kemudian melakukan semua tindakan kita dengan Maria, dalam Maria, melalui Maria, dan untuk

\footnotetext{
21 Konsekrasi merupakan tindakan yang terpisah dari hal umum dan duniawi untuk maksud yang suci, atau melaluinya orang atau benda didedikasikan untuk pelayanan dan devosi kepada Allah lewat doa, ritual, upacara.
} 
Maria." 22 Oleh sebab karya dan pemikiran Montfort ini, dia terkenal sebagai Apostle of Mary.

Secara khusus Montfort memiliki pengaruh yang sangat besar di dalam kehidupan Paus Yohanes Paulus II (Masa Jabatan: 16 Oktober 1978 - 2 April 2005). Paus Yohanes Paulus II bukan hanya menghormati Montfort, dia juga mengatakan bahwa ketika membaca buku True Devotion (Bakti Sejati) karangan Montfort, itu merupakan titik balik di dalam hidupnya. Dia pernah berpendapat bahwa jika devosi kepada Maria dikembangkan secara berlebihan, pada akhirnya dapat mengalahkan devosi yang seharusnya diberikan kepada Kristus. ${ }^{23}$ Akan tetapi, buku Bakti Sejati milik Montfort menyelesaikan kebingungan Yohanes Paulus II. Montfort mengajarkan bahwa Maria mendekatkan umat kepada Kristus dan membawa umat kepada Kristus jika dipahami di dalam Kristus. Oleh karena ini, Yohanes Paulus II sangat menghormati Montfort. Maka, di dalam Ensikliknya yaitu Redemptoris Mater, Montfort ditekankan sebagai seorang tokoh berpengaruh di antara begitu banyak saksi dan guru spiritualitas Maria. Isi Ensiklik Redemptoris Mater itu berbunyi:

Kami hendak menarik perhatian kembali bagi seorang tokoh di antara begitu banyak saksi dan guru spiritualitas Maria, yaitu Santo Louis-Marie Grignion de Montfort, yang mengusul kepada umat Kristiani agar mempersembahkan diri kepada Kristus melalui tangan Maria sebagai sarana yang ampuh untuk menghayati janji-janji baptisnya dengan setia. ${ }^{24}$

Fenomena - fenomena umat Katolik berelasi dengan Maria melalui doa, patung-patung, gambar, stigmata ${ }^{25}$ Maria, sudah dianggap umum

\footnotetext{
22 St. Louis de Montfort, The Secret of Mary, Reprint ed. (Rockford: TAN Books, 1998), No. 28. Kutipan Inggris: Consists in surrendering oneself in the manner of a slave to Mary, and to Jesus through her, and then performing all our actions with Mary, in Mary, through Mary, and for Mary. 23 Yohanes Paulus II, Kurnia dan Misteri: ulang tahun imamatku yang ke 50 (Jakarta: OBOR, 1997), 32.

24 J. Patrick Gaffney, Hidup dan Spiritualitas Santo Louis-Marie De Montfort (Bandung: Serikat Maria Montfortan, 1988), 1, 22. (R.M. No. 48).

25 Dari bahasa Yunani yang berarti "tanda-tanda." Gereja menggunakan kata ini untuk luka-luka, birat/ bekas luka, atau tanda di kulit yang muncul pada diri individu. Gereja menyesuaikannya dengan luka penderitaan Kristus di atas kayu salib. Tanda ini disertai
} 
bagi umat Katolik. Bahkan mereka dapat memfokuskan diri kepada praktek-praktek tersebut tanpa mengetahui praktek tersebut berdasarkan pengajaran Firman Tuhan atau tidak. Mereka menganggap itu sebuah ajaran dan tindakan yang benar. Umat Katolik didorong untuk berelasi bukan hanya kepada Yesus Kristus, tetapi juga kepada Maria. Konsep unik yang dimiliki Montfort di dalam melakukan devosi Mariawi adalah kalimatnya yang tertulis dalam karyanya yaitu True Devotion to Mary. Kalimat tersebut berbunyi demikian:

If then we are establishing sound devotion to our Blessed Lady, it is only in order to establish devotion to our Lord more perfectly, by providing a smooth but certain way of reaching Jesus Christ. If devotion to our Lady distracted us from our Lord, we would have to reject it as an illusion of the devil. But this is far from being the case. As I have already shown and will show again later on, this devotion is necessary, simply and solely because it is a way of reaching Jesus perfectly, loving him tenderly, and serving him faithfully. ${ }^{26}$

Montfort mengakui bahwa Maria tidak lebih tinggi jabatannya dari Allah, dan Yesus Kristus yang seharusnya menjadi tujuan akhir untuk ditinggikan. Hanya saja, Montfort tetap menganggap bahwa seorang tidak dapat memperoleh persatuan yang mesra dengan Tuhan dan kesetiaan yang sempurna kepada Roh Kudus, apabila ia tidak berhubungan secara sungguh-sungguh dengan Perawan tersuci dan bergantung sepenuhnya pada bantuan wanita ini. ${ }^{27}$ Berdasarkan hal ini, teologi devosi Mariawi menurut Montfort dikenal sebagai konsekrasi kepada Yesus Kristus melalui tangan Maria.

dengan rasa sakit yang besar dan dapat dilihat mata. Robert C. Broderick, ed., Catholic Encyclopedia, Reprint ed. (Nashville: Thomas Nelson, 1990), 564.

26 Montfort, Bakti Sejati kepada Maria, 64. Terjemahan: Kalau kita menyebarluaskan devosi yang kokoh kepada Perawan Tersuci, maka kita melakukannya hanya supaya devosi kepada Yesus Kristus disebarkan dengan lebih sempurna. Kita tidak punya maksud lain daripada menawarkan suatu sarana yang mudah dan terjamin untuk menemukan Yesus Kristus. Andaikata devosi kepada Perawan suci menjauhkan kita dari Yesus Kristus, maka kita harus menolaknya sebagai penyesatan setani. Tetapi hal sebaliknyalah yang benar.

27 Ibid., 51. 
Montfort juga mengungkapkan bahwa Maria merupakan pribadi yang tidak bisa dipisahkan ketika manusia berelasi dengan Allah. Dia mengatakan:

You never think of Mary without Mary thinking of God for you. You never praise or honour Mary without Mary joining you in praising and honouring God. Mary is entirely relative to God. Indeed I would say that she was relative only to God, because she exists uniquely in reference to him. ${ }^{28}$

Montfort bermaksud menjelaskan bahwa Maria memiliki relasi yang erat dengan Roh Kudus. Di dalam tubuh Maria, Roh Kudus tinggal dan inkarnasi dalam Yesus Kristus. Oleh karena itu, Montfort memperlihatkan realita dengan menyebut Maria sebagai pasangan setia dari Roh Kudus. Namun bukan berarti Roh Kudus bergantung kepada Maria untuk mengerjakan inkarnasi, sebab Roh Kudus adalah Allah yang memiliki kemampuan mencipta. Ini merupakan misteri anugerah yang diberikan Allah kepada Maria untuk memiliki persekutuan erat dengan Roh Kudus. Melalui Roh Kudu dan Maria, mereka menghasilkan AllahManusia yaitu Yesus Kristus. Selain menyebut Roh Kudus dan Maria merupakan pasangan, Montfort juga mengatakan mereka sebagai "inseparable spouse", sebab Roh Kudus tidak pernah tidak mengakui Maria, karena Maria selalu setia dan berbuah. Bagi gereja Tuhan, Maria adalah model kesediaan dan kepatuhan kepada Allah. Bukan hanya itu, gereja Tuhan dapat belajar mengenai kekudusan, kesucian, dan kedewasaan Maria.

Montfort mengatakan bahwa devosi Mariawi merupakan perfect way untuk melakukan perjalanan menuju relasi yang intim dan persatuan dengan Kristus. ${ }^{29}$ Yesus memilih jalan untuk turun ke dalam dunia melalui Maria, demikian juga umat percaya dapat naik kepada Allah Mahakuasa (Yesus Kristus sendiri) dengan cara yang sempurna melalui Maria. Devosi Mariawi Montfort terdiri dari konsekrasi

\footnotetext{
28 Ibid., poin 225.

29 Ibid., poin 227.
} 
seutuhnya kepada Perawan Teramat Suci supaya melalui Maria, umat percaya menjadi milik Yesus Kristus sepenuhnya. Montfort menganjurkan bahwa umat percaya harus memberikan segala sesuatu kepada Maria. Contohnya adalah tubuh umat percaya beserta semua indera dan anggota tubuh, jiwa dengan seluruh kemampuannya, harta fisik baik saat kini dan masa yang akan datang, dan harta batiniah dan rohani yaitu pahala, keutamaan, dan karya amal di masa lalu, masa kini, dan masa yang akan datang. ${ }^{30}$

\section{Spiritualitas Katolik}

Spiritualitas Montfort merupakan spiritualitas berdasarkan pemikirannya tentang Maria. Menurut asal katanya, spiritualitas berasal dari bahasa Latin yaitu spiritualitas (kata benda), dan spiritualis (kata sifat). Kata spiritualitas ini sifatnya tidak bertentangan dengan fisik atau materi, melainkan daging yang melawan Roh Allah. ${ }^{31}$ Beberapa ciri spiritualitas Katolik yang dipaparkan oleh Bushman ${ }^{32}$; Pertama yaitu Kristosentris. Kristus yang menciptakan hidup rohani dan spiritualitas Katolik tergantung dari semua pengajaran Kristus. Kedua, melalui Kristus menuju kesatuan dengan Allah Tritunggal. Ketika manusia bersatu dengan Kristus, maka akan bersatu dengan Allah Tritunggal. Ketiga, partisipasi dalam misteri paska Kristus (salib, kebangkitan dan kenaikanNya ke surga), melalui anugerah Allah, iman, kasih, dan nilai-nilai Kristiani lainnya. Spiritualitas Katolik tidak terlepas dari salib Kristus, penderitaan-Nya, serta kesadaran diri akan dosa-dosa yang membawa umat Allah pada kebangkitan di dalam Dia. Ketika menerima salib Kristus, maka menerima segala kemuliaan dan penderitaan yang ada pada salib tersebut. Keempat, Berdasarkan kesaksian kasih Allah. Kitab

\footnotetext{
30 Hubert Hechtermans, Alles of Niets (Oirschot: Nederlandse Provincie van de Montfortanen, 1998). Buku Terjemahan Indonesia: Seluruhnya atau Tidak Sama Sekali, 257.

31 Philip Sheldrake, Spirituality: a Brief History, 2nd ed. (Hoboken: Wiley-Blackwell, 2013),

2.

32 Douglas G. Bushman, S.T.L., Foundation of Catholic Spirituality (Institute for Pastoral Theology, Ave Maria University: 2006), 35-37.
} 
Suci bukan hanya wahyu Allah, tapi juga pernyataan akan pengalaman manusia di dalam wahyu Allah itu. Apa yang dialami oleh Adam dan Hawa, Abraham, Ayub, Bunda Maria, Rasul Petrus dan Paulus, dapat dialami oleh setiap umat. Kelima, disertai kesadaran akan dosa dan belas kasihan Allah. Spiritualitas Katolik berlandaskan atas keyakinan akan kasih Allah di atas segalanya yang mampu mengubah segala sesuatu. Pada saat Allah mengasihi umat-Nya, dan jika umat-Nya membuang segala dosa yang menghalangi menerima kasih-Nya, dan dengan iman dan doa, maka umat-Nya dapat sungguh diubah, dikuduskan dan dimampukan berbuat baik. Keenam, memiliki arah pada kehidupan kekal yang dijanjikan oleh Allah. Ketujuh, melihat Bunda Maria sebagai teladan. Spiritualitas Katolik menerima segala kebijaksanaan Allah yang selalu menggunakan peran pengantara, yaitu Musa, para nabi, Yohanes Pembaptis, dan terutama Bunda Maria untuk menyelenggarakan karya keselamatan Allah. Karya Allah yang ajaib terlihat dalam mukjizat keperawanan Maria, ketaatan, kesediaan Maria, dan Allah yang memberikan anugerah yang tiada batasnya, yaitu kelahiran Yesus Kristus. Kedelapan, mengacu pada Gereja-Nya yaitu Gereja Katolik. Gereja merupakan alat yang meneruskan anugerah Allah. Anugerah Allah diperoleh umat-Nya melalui sakramen-sakramen, terutama Ekaristi.

\section{Komparasi Dasar Spiritualitas Reformed dan Katolik}

Terdapat perbedaan yang kontras antara spiritualitas Reformed dan spiritualitas Katolik. Salah satu teolog yang memaparkan dengan jelas mengenai spiritualitas Reformed adalah Alister E. McGrath. McGrath menjelaskan bahwa spiritualitas Reformed berbicara mengenai respons pribadi atau sekelompok orang percaya terhadap aktivitas kebaikan Allah dan pribadi Allah yang mencakup setiap aspek kehidupan. Empat prinsip spiritualitas Reformed yang dipaparkan McGrath ${ }^{33}$; Pertama, didasarkan dan dipelihara dalam pembelajaran

\footnotetext{
33 Alister E. McGrath, Spirituality in an Age of Change: Rediscovering the Spirit of the Reformers (Grand Rapids: Zondervan, 1994), 42-57.
} 
Kitab Suci/ Sola Scriptura. Kitab Suci merupakan otoritas tertinggi dan pemberian Allah untuk generasi Kristen dan pemeliharaan iman Kristen. Berdasarkan prinsip ini, para reformator melakukan hal praktis yang pertama yaitu uraian biblikal (Biblical commentary). Uraian ini ditujukan agar orang-orang percaya dapat mengerti Firman Tuhan, menjelaskan kata-kata sulit, mengidentifikasi hal-hal penting, dan membuat pembaca lebih terbiasa membaca Kitab Suci. Kedua yaitu khotbah ekspositoris. Salah satu contohnya adalah khotbah Calvin di Jenewa yang bersifat lectio continua (Continued reading) yaitu khotbah berkelanjutan/ berurut dari Kitab Suci. Dalam periode 20 Maret 1555 - 15 Juli 1556, Calvin dikenal pernah berkhotbah sebanyak 200 kali dari satu kitab yaitu Kitab Ulangan. Calvin juga pernah berkhotbah sebanyak 123 kali dari Kitab Kejadian. ${ }^{34}$ Ketiga, karya-karya teologi alkitabiah. Calvin membuat karya agungnya Institutes of the Christian Religion dengan tujuan agar pembaca memperoleh sudut pandang yang koheren dan konsisten mengenai Kitab Suci. Sudut pandang terhadap Kitab Suci ini menjadi dasar praktek kehidupan sehari-hari. Kedua, menegaskan bahwa penyelidikan terhadap identitas, kebenaran, dan pemenuhan manusia tidak bisa dikerjakan tanpa pribadi Allah. Jalan untuk mengenal identitas diri manusia adalah dengan mengenal identitas Allah sebagai Pencipta manusia. Akibatnya, penekanan segala pengetahuan dan kebenaran adalah berasal dari inisiatif pewahyuan Allah. Ketiga, secara eksplisit mengakui keimaman dan panggilan seluruh orang-orang percaya. Spiritualitas Reformed tidak mengakui pembedaan status sosial dan tingkat-tingkat kependetaan dalam kehidupan religius. Setiap rohaniwan dan orang Kristen awam memiliki hak dan akses yang sama untuk mempelajari agama dan Kitab Suci. Jadi intinya adalah pemulihan ide kaum awam sebagai laos (Yunani) yaitu people of God. Keempat, diorientasikan pada kehidupan setiap hari di dunia, yaitu memampukan orang-orang percaya hidup dengan iman yang teguh di dunia sekuler.

\footnotetext{
34 Howard L. Rice, Reformed Spirituality: An Introduction for Believers (Louisville: Westminster John Knox Press, 1991), 106.
} 
Dengan kata lain, memampukan orang-orang percaya menjadi terang dan garam dunia. Orang-orang Kristen tidak didorong untuk menarik diri dari lingkungan dunia yang berdosa lalu masuk ke biara dan tidak peduli dunia sekitar, melainkan tetap hadir di dunia dan membawa dampak yang benar ke dalam dunia.

McGrath menambahkan bahwa spiritualitas Reformed berkaitan dengan teologinya. Spiritualitas merupakan hal konkrit/ ekspresi dari teologi. Dengan demikian, dalam memahami spiritualitas Reformed, dibutuhkan pengertian yang komprehensif terhadap Teologi Reformed. Teologi Reformed yang dimaksudkan penulis dalam karya tulis ini adalah teologi berdasarkan tokoh reformator Perancis bernama John Calvin. Teologi John Calvin sangat dipengaruhi oleh reformator Jerman bernama Martin Luther. Luther melihat bahwa inti Injil adalah doktrin pembenaran oleh anugerah semata (sola gratia) melalui iman semata (per solam fidem) karena Kristus semata (solus Christus). ${ }^{35}$ Dalam perkembangan Teologi Reformed, terdapat lima pilar yang menjadi dasar: ${ }^{36}$ Pertama, Sola Gratia (Grace Alone). Pada tingkat pertama, ajaran ini dimengerti sebagai keyakinan bahwa manusia berdosa memiliki jalan untuk diselamatkan. Keselamatan hanya berasal dari anugerah Allah saja, bukan karena kebaikan manusia. Pada tingkat kedua, anugerah Allah membuat manusia mengenal Allah sejati yaitu Yesus Kristus. Allah sebagai inisiator yang memberikan pengetahuan akan Allah (knowledge of God) dan pengetahuan akan manusia (knowledge of man) kepada manusia. Kedua, Sola Fide (Faith Alone). Anugerah yang menyelamatkan dari Allah diperoleh manusia melalui iman. Calvin mengerti bahwa iman merupakan pekerjaan Roh Kudus dan tugas utama Roh Kudus adalah mempersatukan orang-orang pilihan dengan Kristus (Union with Christ). Oleh karena persatuan dengan Kristus ini, iman orang-orang percaya dipelihara. Untuk menghindari konsep pembenaran hanya oleh iman

\footnotetext{
35 Joel R. Beeke, Puritan Reformed Spirituality (Darlington: Evangelical Press, 2006$), 377$.

36 William Stacy Johnson, John Calvin, Reformer for the 21st Century (Louisville: Westminster John Knox Press, 2009), 22-28.
} 
lalu akhirnya mengabaikan kehidupan yang bermoral, Calvin mengajarkan doktrin anugerah ganda (double grace). Bentuk anugerah pertama yaitu justification, pembenaran oleh iman di hadapan Allah. Bentuk anugerah kedua yaitu sanctification, pengudusan diri terusmenerus sepanjang hidup. Ketiga, Solus Christus (Christ Alone). Hanya Kristus yang dapat menyelamatkan jiwa manusia dan hanya Kristus Pengantara antara Allah dengan manusia. Dalam konteks abad 16, hal ini menyatakan bahwa gereja bukanlah pengantara keselamatan. Keempat, Sola Scriptura (Scripture Alone). Pada abad 16 Gereja Katolik mengakui otoritas kebenaran tertinggi adalah Kitab Suci dan tradisi gereja. Sedangkan para reformator mengakui bahwa otoritas kebenaran tertinggi hanyalah Kitab Suci. Pada konteks kehidupan Calvin, khotbah dari Kitab Suci merupakan pusat dari ibadah religius dan setiap elemen dalam penyembahan harus datang dari Kitab Suci. Calvin berkata "We speak where Scripture speaks, and are silent where Scripture is silent." 37 Oleh karena itu, manusia perlu menjalankan apa yang dikatakan Kitab Suci. Sedangkan apa yang tidak dikatakan Kitab Suci, maka manusia tidak perlu menjalankannya. Kelima, Soli Deo Gloria (Glory be to God Alone). Segala hal harus diberikan untuk kemuliaan Allah. Pilar ini dikenal juga sebagai doksologi yang menjadi visi Calvin bagi gereja Reformed untuk berhadapan dengan dunia. ${ }^{38}$

Berbeda dengan spiritualitas Reformed, spiritualitas Katolik memiliki 3 pilar yang menjadi sumber iman dan kebenaran orang-orang percaya. Pertama, Kitab Suci (Sacred Scripture). Dalam Kitab Suci ini, Katolik mengakui 72 kitab (termasuk Deuterokanonika ${ }^{39}$ ) sebagai Firman Allah yang diinspirasikan Roh Kudus. Kedua, Tradisi Suci (Sacred Tradition), yaitu ajaran dari Bapa Gereja dan ajaran para Rasul di mana

\footnotetext{
37 McGrath, Spirituality in an Age of Change, 43.

38 Johnson, John Calvin, Reformer for the 21st Century, 128.

39 Berasal dari kata Yunani deuterocanonical yang berarti "belonging to the second canon." Buku-buku yang termasuk kanon kedua ini merupakan bagian dalam Perjanjian Lama yang bukan bagian dari Alkitab Ibrani dan diakui oleh Gereja Katolik.
} 
para Rasul memperoleh ajaran dan teladan dari Yesus dan Roh Kudus. ${ }^{40}$ Bentuk tradisi suci ini dapat berupa keputusan konsili-konsili gereja, tulisan orang kudus, dan Katekismus Gereja Katolik. Ketiga, Magisterium Gereja (Living Magisterium), yaitu ajaran dari Paus dan para Uskup Roma, sebagai penerus Rasul Petrus, yang dipercaya untuk meneruskan pengajaran para Rasul (tertulis/ lisan). Magisterium bertugas untuk menginterpretasikan ajaran Injil sesuai dengan maksud aslinya, dan meneruskannya kepada gereja. ${ }^{41}$ Keputusan dan ajaran dari Magisterium ini dapat berupa ensiklik, surat apostolik, konstitusi apostolik, keputusan konsili-konsili, dll. Melalui ketiga pilar ini, Gereja menerima wahyu Allah yang dinyatakan dalam Injil. Ketiga pilar ini saling berkaitan antara satu dengan lainnya. Berdasarkan sumber yang berbeda ini, maka otomatis iman dan pengajaran yang diajarkan kedua spiritualitas ini berbeda, meskipun dalam hal-hal tertentu terdapat kesamaan.

Spiritualitas Reformed menolak 2 sumber yang lain dari Katolik sebab bagi spiritualitas Reformed, tradisi suci dan ajaran gereja tidak memiliki otoritas yang setara dengan Alkitab. Alasan mengapa spiritualitas Katolik mengembangkan doktrin Mariologi adalah akibat dari 2 sumber kebenaran yang mereka anut yaitu tradisi suci dan ajaran gereja. Spiritualitas Reformed tidak mengajarkan Mariologi seperti yang dipahami Katolik sebab sumber kebenarannya hanya berdasarkan Kitab Suci. Spiritualitas Reformed mengakui satu-satunya otoritas dan sumber kebenaran adalah Kitab Suci dan segala kebenaran yang diajarkan berdasarkan kebenaran Alkitab (2 Timotius 3:16). Tradisi gereja dan ajaran gereja yang tidak didasarkan pada kebenaran Alkitab menjadi hal yang tidak diterima oleh spiritualitas Reformed. Sedangkan tradisi dan ajaran gereja yang sesuai kebenaran Alkitab bukanlah masalah.

\footnotetext{
40 Stefanus Tay \& Ingrid Listiati Tay. Maria, O Maria - Bunda Allah, Bundaku, Bundamu. (Surabaya: Murai Publishing, 2016), xv.

41 Ibid., xvii.
} 
Perbedaan yang lain adalah tindakan devosi kepada manusia dan penyembahan kepada Allah. Terdapat perbedaan kualitas antara Pencipta dan makhluk hidup. Pencipta dan makhluk hidup memiliki tingkatan kemuliaannya masing-masing. Spiritualitas Katolik membagi tingkatan kemuliaan makhluk menjadi 5 tingkatan. Tingkat pertama yang berada di posisi paling atas adalah Allah Tritunggal. Kedua, Bunda Maria. Ketiga, para malaikat dan orang-orang kudus. Keempat, manusia, dan yang terakhir Setan. Oleh karena posisi Bunda Maria berada setelah posisi Allah, maka spiritualitas dan devosi Mariawi dalam Katolik sangat berkembang. Alasan lain spiritualitas Mariawi begitu berkembang adalah karena adanya pendekatan iman melalui Tradisi Suci dan Magisterium. Kitab Suci memang mengajarkan spiritualitas Mariawi sebagai ibu Yesus dan hamba Tuhan yang bijaksana, rendah hati, dan setia kepada Tuhan. Akan tetapi Kitab Suci tidak mengajarkan untuk fokus mengenal dan berelasi dengan pribadi Maria sama seperti fokus mengenal dan berelasi dengan pribadi Allah. Oleh karena dua sumber iman selain Kitab Suci inilah yang membuat spiritualitas Mariawi dalam spiritualitas Katolik berkembang dan dianggap sebagai kebenaran.

Sedangkan spiritualitas Reformed memiliki 4 tingkatan yaitu Allah Tritunggal, malaikat, manusia, dan setan. Bunda Maria tidak memiliki posisi sendiri, melainkan sama seperti umat manusia berdosa pada umumnya. Penulis membuat gambar tingkatan antara Pencipta dan makhluk hidup:

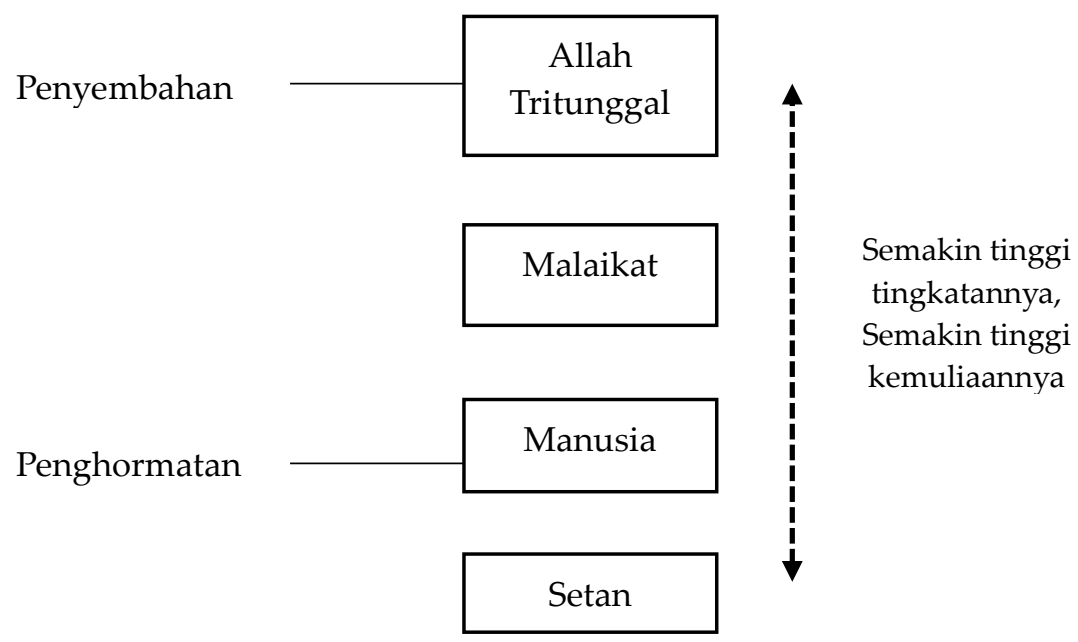




\section{Konsep dan Praktek Devosi Teologi Reformed}

Johnson menganalisa pendekatan Calvin terhadap kehidupan spiritual dan penyembahan kepada Allah. Calvin mengembangkan beberapa pendekatan. Pertama, dia sangat menekankan penjelasan Firman Tuhan dari Kitab Suci di dalam setiap khotbah. Dia menempatkan kekuatan dan kejelasan khotbah sebagai hal utama. ${ }^{42}$ Dengan dasar ini, jemaat yang dikatakan menyembah dan menghormati Allah adalah jemaat yang melakukan pembelajaran Firman Tuhan dengan giat melalui pendengaran dan melakukan Firman Tuhan. Kedua, di tengah-tengah praktek devosi zaman pertengahan yang boros dan royal, Calvin mengambil posisi yang kontras yaitu kesederhanaan. Calvin menganggap praktek devosi di gereja abad pertengahan merupakan distraksi besar-besaran dari ibadah yang benar dan merupakan sebuah praktek agama pagan. ${ }^{43}$ Calvin menentang gambargambar yang melukiskan keilahian Allah berdasarkan pengajaran Musa melalui 10 Hukum Taurat. Ketiga, Calvin tidak menekankan kalender gereja. Di Jenewa tidak ada ibadah Natal khusus dan Calvin mengeliminasi ritual yang berhubungan dengan puasa 40 hari. Bukan hanya itu, Calvin mendorong agar jemaat menyanyikan pujian dari ayatayat dalam Kitab Mazmur. Keempat, perubahan kekuasaan pada kaum rohaniwan dan awam. Kaum awam memiliki tanggung jawab lebih dalam pelayanan gerejawi. Misalnya di Jenewa, kaum awam juga memiliki tanggung jawab untuk memperhatikan orang-orang miskin. Calvin berusaha untuk meminimalisir perbedaan antara tingkatan antara rohaniwan dan awam sehingga perbedaannya bukan pada status melainkan karunia rohani dan tanggung jawab pastoral.

\section{Tanggapan Kritis terhadap Teologi Devosi Mariawi Montfort}

Latar belakang kehidupan Montfort sangat memengaruhi spiritualitas Mariawi milik Montfort. Dalam masa awal pelayanan

42 Johnson, John Calvin, Reformer for the 21st Century, 97-98.

43 Ibid., 99. 
apostoliknya, Montfort mengambil jalan hidup kemiskinan, berjanji di hadapan patung Maria untuk panggilannya sebagai Imam, berminta pada pembelajaran Kitab Suci, dan berkhotbah kepada orang-orang biasa yaitu orang-orang di Barat Laut Perancis. ${ }^{44}$ Montfort beriman bahwa panggilan Allah atas hidupnya adalah menjadi seorang pasukan pemberani bagi Yesus dan Maria, membentuk sekelompok pasukan pria dan wanita untuk bertarung melawan dunia, dan menjadi rasul sejati pada zamannya. ${ }^{45}$ Dalam mewujudkan panggilannya, Montfort memiliki pemikiran utama dalam teologinya tentang devosi Mariawi yaitu konsekrasi hidup kepada Yesus melalui Maria. Konsekrasi ini diklasifikasikan oleh Montfort sebagai tindakan penyembahan Latria. ${ }^{46}$ Dasar pertama dari teologi devosi Mariawi menurut Montfort adalah Trinitarian dan Kristosentris. Hal ini terlihat dalam tulisan Montfort yang dikutip oleh Gaffney"7 "Jesus Christ, Our Savior, true God and true Man, must be the final goal of all our other devotions, else they are false and delusive." 48 Montfort juga memparalelkan pribadi Maria dengan Yesus Kristus:

Ask Jesus living in Mary that his kingdom may come upon earth through his holy Mother. Ask for divine Wisdom, divine love, the forgiveness of your sins, or any other grace, but always through Mary and in Mary. Cast a look of reproach upon yourself and say, "Lord, do not look at my sins, let your eyes see nothing in me but the virtues and merits of Mary." Remembering your sins, you may add, "I am my own worst enemy and I am guilty of all these sins." Or, "Deliver me from the unjust and deceitful man." Or again, "Dear Jesus, you must increase in my soul and I must decrease." "Mary, you must increase in me and I must always go on decreasing." "O Jesus and Mary, increase in me and increase in others

\footnotetext{
44 Gaffney, Hidup dan Spiritualitas Santo Louis-Marie De Montfort, 5-6.

45 Montfort. Bakti Sejati kepada Maria, 114, 58.

46 Latria merupakan klasifikasi Katolik dalam penyembahan yang ditujukan hanya kepada Allah Tritunggal. Tindakan konsekrasi ini disamakan dengan pembaruan Baptis, ditujukan kepada Yesus Kristus. Berulangkali juga Montfort menekankan motonya yaitu God Alone sebagai tujuan akhir seluruh devosi kepada Maria.

47 J. Patrick Gaffney, "St. Louis Mary Grignion De Montfort and the Marian Consecration," dalam Marian Studies, Vol. 35, Article 14, (1984): 117.

48 Montfort. Bakti Sejati kepada Maria, 61.
} 
around me. $^{49}$

Dalam penilaian penulis, meskipun dasar teologi devosi ini Trinitarian dan Kristosentris, namun praktek yang terjadi dalam spiritualitas umat Katolik membawa spiritualitas umat Katolik kepada 2 unsur yaitu Mariosentris dan Mariolatri. ${ }^{50}$ Unsur pertama Mariosentris, maksudnya adalah tujuan akhir dari praktek-praktek devosi umat Katolik seperti objek ibadah, pemberitaan Firman Tuhan/ khotbah, tulisan, doa, pujian gerejawi, dan liturgi ibadah gereja adalah pribadi Maria, bukan pribadi Allah. Misalnya Paus John Paul II yang mendapat pengaruh besar dari tulisan Montfort, dia memanjatkan doa terkenal yaitu totus tuus/ completely yours. Doa ini tidak diarahkan kepada Allah Tritunggal, tetapi kepada Maria..51 Doa tersebut berbunyi "Totus tuus ego sum, et omnia mea tua sunt. Accipio te in mea omnia. Praebe mihi cor tuum, Maria." 52 Doa ini menunjukkan sebuah sikap penuh untuk menyerahkan diri kepada Maria dan tinggal di dalam Maria. Maka meskipun Montfort menekankan Kristosentris dalam devosinya kepada Maria, tetapi praktek yang terjadi dapat berupa Mariosentris. Sedangkan berdasarkan Filipi 1:21 dan Roma 12:1,53 Paulus menekankan untuk memiliki sikap penuh untuk menyerahkan diri kepada Yesus dan tinggal dalam-Nya, bukan pada Maria.

Unsur kedua yaitu Mariolatri, maksudnya adalah praktek devosi yang seharusnya ditujukan kepada 1 objek, sekarang dilakukan terhadap 2 objek yaitu Allah dan Maria. Umat Katolik memiliki tambahan objek ibadah yang baru yaitu pribadi Maria. Di dalam Mariolatri ini, praktek

\footnotetext{
49 Louis-Marie Grignion De Montfort. True Devotion to Mary (Rockford: Tan, 1985), poin 272.

50 Secara literal "Mary Worship", atau sebuah praktek penyembahan Maria sebagai berhala.

51 Herbert Carson, The Faith of the Vatican: A Fresh Look at Roman Catholicism (Durham: Evangelical, 1996), 107-108.

52 Terjemahan Inggris: "I belong entirely to you, and all that I have is yours. I take you for my all. O Mary, give me your heart."

53 "For to me to live is Christ, and to die is gain." ESV. Phil. 1:21.

"I appeal to you therefore, brothers, by the mercies of God, to present your bodies as a living sacrifice, holy and acceptable to God, which is your spiritual worship." ESV. Rom. 12:1
} 
devosi yang dilakukan kepada Allah sama persis dengan devosi yang dilakukan kepada Maria. Penulis membuat perbandingan praktek devosi yang dilakukan kepada Allah dan kepada Maria:

\begin{tabular}{|c|c|c|c|}
\hline Aspek & Allah Tritunggal & Maria & Penilaian \\
\hline Iman & $\begin{array}{c}\text { Keselamatan dan } \\
\text { berkat }\end{array}$ & $\begin{array}{c}\text { Keselamatan dan } \\
\text { berkat }\end{array}$ & Sama \\
\hline Perbuatan & $\begin{array}{c}\text { Diarahkan kepada } \\
\text { Allah }\end{array}$ & $\begin{array}{c}\text { Diarahkan kepada } \\
\text { Maria }\end{array}$ & Sama \\
\hline $\begin{array}{l}\text { Doa \& } \\
\text { Puasa }\end{array}$ & $\begin{array}{c}\text { Pengagungan dan } \\
\text { permohonan doa } \\
\text { disampaikan kepada } \\
\text { Allah } \\
\end{array}$ & $\begin{array}{c}\text { Pengagungan dan } \\
\text { permohonan doa } \\
\text { disampaikan kepada } \\
\text { Maria } \\
\end{array}$ & Sama \\
\hline Firman & $\begin{array}{c}\text { Allah menyatakan } \\
\text { kehendak-Nya; } \\
\text { firman-Nya dihormati } \\
\text { \& dipercaya }\end{array}$ & $\begin{array}{l}\text { Maria menyatakan } \\
\text { kehendaknya; } \\
\text { firmannya dihormati } \\
\text { dan dipercaya }\end{array}$ & Sama \\
\hline Pujian & $\begin{array}{l}\text { Menyanyikan lagu } \\
\text { pujian kepada Allah }\end{array}$ & $\begin{array}{l}\text { Menyanyikan lagu } \\
\text { pujian kepada Maria }\end{array}$ & Sama \\
\hline $\begin{array}{c}\text { Hari } \\
\text { peringatan }\end{array}$ & $\begin{array}{l}\text { Natal, Jumat Agung, } \\
\text { Paskah, Pentakosta. }\end{array}$ & $\begin{array}{c}\text { Terdapat } 14 \text { hari } \\
\text { peringatan }\end{array}$ & Sama \\
\hline Liturgi & Doa Bapa Kami & Doa Salam Maria & Sama \\
\hline Sakramen & Ada & Tidak ada & Berbeda \\
\hline
\end{tabular}

Berdasarkan tabel di atas, hanya 1 perbedaan praktek devosi yang dilakukan kepada Allah dan Maria, yaitu dalam aspek sakramen. Sedangkan ketujuh aspek lainnya memiliki praktek devosi yang sama. Padahal Montfort sendiri berpandangan bahwa jika devosi kepada Maria menjauhkan diri umat dari Yesus Kristus, maka devosi tersebut harus ditolak sebagai kesesatan. Masalahnya, umat Kristen sangat mungkin memiliki pemikiran dan perasaan bahwa mereka memiliki relasi yang dekat dengan Yesus Kristus dan dekat juga dengan Maria. Manusia 
memang memiliki kemampuan untuk memiliki berhala lain selain dari Allah sendiri. Pada dasarnya, segala devosi kepada Maria dalam spiritualitas Katolik maupun teologi devosi Mariawi Montfort yang Kristosentris, merupakan tindakan yang bertentangan dengan Hukum Taurat pertama dan kedua. Sebab devosi kepada Maria mengajarkan umat untuk datang kepada Maria terlebih dahulu untuk dapat datang kepada Kristus. Alkitab mengatakan bahwa hukum 1 mengajarkan objek ibadah yang benar yaitu Allah sebagai pribadi yang mutlak dan terpenting, hukum 2 mengajarkan cara ibadah yang benar yaitu menghampiri Allah. ${ }^{54}$ Ajaran ini sesuai dengan prinsip Sola Scriptura yang diajarkan Calvin bahwa di mana Alkitab bersuara, di sana umat percaya menjalankannya. Di mana Alkitab hening, di sana umat juga hening. Berarti apa yang diperintahkan Alkitab itu yang dikerjakan umat percaya sedangkan yang tidak diperintahkan Alkitab, tidak dikerjakan oleh umat percaya.

Dasar kedua teologi devosi Mariawi menurut Montfort adalah ketidakterpisahan antara pribadi Allah Tritunggal dan Maria. Yang dimaksudkan Montfort bukan berarti menyamakan status dan kemuliaan Maria setara dengan Allah, melainkan kehendak Maria selalu memiliki kehendak yang sama dengan kehendak Allah. Montfort tahu bahwa Maria tidak mungkin menyempurnakan Allah atau lebih tinggi posisinya dari Allah. Maria jauh di bawah Allah. Maksud Montfort adalah karena anugerah Allah yang begitu besar terhadap Maria, maka Maria terlihat memiliki kekuasaan seperti Allah. Di manapun Yesus berada, Yesus selalu menjadi Anak Maria. Montfort katakan bahwa Maria tetap bersama Yesus, "the inseparable companion of His life, of His death, of His glory and of His power in heaven and upon earth." 55 Bukan hanya itu, posisi Maria terhadap Roh Kudus adalah sebagai pasangan Roh Kudus:

God the Holy Ghost being barren in God - that is to say, not producing another Divine Person-is become fruitful by Mary, whom He has

54 G.I. Williamson, Katekismus Singkat Westminster Vol. 2 (Surabaya: Momentum, 2009), 14.
55 Montfort, Bakti Sejati kepada Maria, 74. 
espoused. It is with her, in her, and of her, that He has produced His Masterpiece, which is a God made Man, and whom He goes on producing in the persons of His members daily to the end of the world. The predestinate are the members of that Adorable Head. This is the reason why $\mathrm{He}$, the Holy Ghost, the more He finds Mary, His dear and indissoluble Spouse, in any soul, becomes the more active and mighty in producing Jesus Christ in that soul, and that soul in Jesus Christ. ${ }^{56}$

Oleh karena posisi Maria adalah tetap sebagai Ibu Yesus dan pasangan Roh Kudus, maka doa-doa Maria dianggap begitu berpengaruh dan Allah Tritunggal memandang permohonan doa Maria sebagai perintah. ${ }^{57}$ Allah tidak pernah menolak doa yang dipanjatkan Maria sebab kehendak Maria sama dengan kehendak Allah. Selain itu, spiritualitas Montfortian memiliki tujuan utama yaitu kesatuan dengan Yesus Kristus. Untuk mencapai kesatuan ini, jalan/ alat yang paling utama adalah Maria. Maka Maria tidak dapat dipisahkan dengan Allah Tritunggal. Montfort percaya bahwa satu-satunya sarana mendekatkan diri dengan Yesus adalah melalui Maria, bukan makhluk-makhluk lain. Montfort setuju perkataan Santo Bonaventura yang berkata bahwa Perawan Suci adalah jalan untuk pergi menuju Tuhan. Untuk mencapai kesatuan dengan Kristus, diperlukan pengantara untuk mencapai satusatunya Pengantara tersebut. Pengantara yang membawa umat kepada satu-satunya Pengantara itu adalah Maria. ${ }^{58}$

Menurut penulis, sesuai perkataan Paulus "Karena Allah itu esa dan esa pula Dia yang menjadi pengantara antara Allah dan manusia, yaitu manusia Kristus Yesus, yang telah menyerahkan diri-Nya sebagai tebusan bagi semua manusia: itu kesaksian pada waktu yang ditentukan." (1 Timotius 2:5-6), maka satu-satunya pengantara antara Allah dan manusia adalah Yesus Kristus. Perjanjian Baru menjelaskan bahwa Yesus Kristus adalah Pengantara manusia yang berdosa untuk datang kepada Allah yang suci. Ketika orang dapat datang kepada Yesus Kristus, itu bukan dari pribadi manusia lain yang berdosa melainkan

\footnotetext{
Ibid., 20.

Ibid., 27.

58 Ibid., 86.
} 
pekerjaan Roh Kudus yang melahirbarukan orang tersebut untuk percaya kepada Yesus Kristus. Apabila pandangan Katolik menyatakan bahwa Maria adalah pengantara manusia berdosa kepada Yesus Kristus, maka manusia berdosa lain dapat menjadi pengantara manusia berdosa lainnya. Yesus Kristus sendiri berkata bahwa Dia adalah jalan, kebenaran, dan kehidupan, tidak ada yang datang kepada Allah Bapa kecuali melalui Yesus Kristus (Yohanes 14:6). Untuk datang kepada Allah, manusia memerlukan Pengantara yang tidak berdosa, yaitu Yesus Kristus sendiri. Maria memiliki posisi yang terpisah dan berbeda dengan posisi Allah. Maria sendiri adalah manusia yang berdosa dan tidak memiliki kuasa seperti Pencipta. Sama seperti dalam Ibrani 7:25 mengatakan "Karena itu Ia sanggup juga menyelamatkan dengan sempurna semua orang yang oleh Dia datang kepada Allah. Sebab Ia hidup senantiasa untuk menjadi Pengantara mereka."

Dasar ketiga teologi devosi Mariawi menurut Montfort adalah kekuasaan penuh kasih dan kemuliaan Maria. ${ }^{59}$ Montfort berpandangan bahwa bumi penuh dengan kemuliaan Maria melalui dirinya sebagai penjaga dan pelindung umat. Maria juga akan menguasai bumi bersamasama dengan anak-Nya, Yesus Kristus pada saat kedatangan kedua. Montfort mengatakan bahwa:

The whole earth is full of her glory, especially among Christians, amongst whom she is taken as the protectress of many kingdoms, provinces, dioceses, and cities. Numbers of cathedrals are consecrated to God under her name. There is not a church without an altar in her honour, not a country or a canton where there are not some miraculous images, where all sorts of evils are cured, and all sorts of good gifts obtained. Who can count the confraternities and congregations in her honour? How many religious orders have been founded in her name and under her protection! What numbers there are of Brothers and Sisters of all these confraternities, and of religious men and women of all these orders, who publish her praises and confess her mercies! There is not a little child, who, as it lisps the Ave Maria, does not praise her. There is scarcely a sinner who, even in

\footnotetext{
59 Walter T. Brennan, "Servants of the Magnificat: The Canticle of the Blessed Virgin and Consecrated Life - Capitular Letter of the 210th General Chapter of the Friars Servants of Mary," Marian Studies Vol. 50, Article 8, (1999): 95.
} 
his obduracy, has not some spark of confidence in her. Nay the very devils in hell respect her while they fear her. ${ }^{60}$

Salah satu pilar utama dari spiritualitas Reformed adalah Soli Deo Gloria. Hal ini sesuai dengan Roma 11:36 yang mengatakan "Sebab segala sesuatu adalah dari Dia, dan oleh Dia, dan kepada Dia: Bagi Dialah kemuliaan sampai selama-lamanya!" Saat kemuliaan yang seharusnya diberikan kepada Allah ini diberikan kepada manusia, maka hal tersebut tidak menghormati Allah. Maria tidak menerima kemuliaan yang seharusnya diterima oleh Allah. Kitab Lukas 21:27 mengatakan bahwa Yesus Kristus akan datang dalam awan dengan segala kekuasaan dan kemuliaan-Nya. Yesus Kristus juga datang seorang diri, tidak bersama dengan Maria. Hal ini berdasarkan Kisah Para Rasul 1:10-11 “Hai orangorang Galilea, mengapakah kamu berdiri melihat ke langit? Yesus ini, yang terangkat ke sorga meninggalkan kamu, akan datang kembali dengan cara yang sama seperti kamu melihat Dia naik ke surga." Saat Yesus naik ke Surga, Dia terangkat seorang diri. Maka sama seperti Yesus naik ke Surga, Dia akan datang kembali ke dunia seorang diri.

Dasar keempat teologi devosi Mariawi menurut Montfort adalah menyeluruh dalam gereja/ Ecclesiastical. Konteks zaman Montfort adalah di mana devosi kepada Maria lebih diabaikan dibandingkan zaman sebelumnya. ${ }^{61}$ Bahkan beberapa teolog Kristen terang-terangan menolak devosi kepada Maria. Montfort memberikan respons terhadap mereka dengan sikap yang cemas dan marah. Montfort mengungkapkan bahwa:

After that we must surely say with the Saints, De Maria nunquam satis, "Of Mary there is never enough"; we have not yet praised, exalted, honoured, loved, and served Mary as we ought to do. She has deserved still more praise, still more respect, still more love, and far more service. ${ }^{62}$

Montfort mengajarkan sisi ilahi dari Maria bahwa Maria memiliki sifat tidak terbatas. Di dalam menghormati dan memuji Maria, umat

\footnotetext{
60 Montfort, Bakti Sejati kepada Maria, 9.

61 Gaffney, Marian Studies Vol. 35, Article 14, (1984): 119.

62 Montfort, Bakti Sejati kepada Maria, 10.
} 
Katolik tidak akan pernah merasa cukup. Dengan demikian, tema-tema tentang Maria merupakan salah satu tema yang diajarkan secara menyeluruh kepada Gereja Katolik. Setzer ${ }^{63}$ mengutip Roschini ${ }^{64}$ berkata bahwa karya Montfort True Devotion to Mary "has exercised and will exercise a great influence on the doctrine and cult of Mary and nowhere have the foundations of Marian devotion been so solidly exposed as in this treatise." 65 Montfort telah memberikan pengaruh besar di dalam teologi dan spiritualitas Katolik mengenai Maria. Pengaruh yang utama terlihat dalam Ensiklik Marialis Cultus, yang khusus berbicara mengenai devosi kepada Maria di dalam Yesus Kristus. Lalu jika melihat sejarah perkembangan Mariologi pada lampiran 3, masa kekosongan perkembangan Mariologi terjadi setelah Konsili Lateran pada tahun 649 sampai Ensiklik Ineffabilis Deus muncul pada tahun 1854. Kehadiran Montfort di masa kekosongan Mariologi yaitu pada tahun 1673 - 1716, merupakan awal baru perkembangan Mariologi pada tahun selanjutnya. Montfort memberikan daya tarik dan stimulus tersendiri terhadap perkembangan devosi kepada Maria di sepanjang sejarah Gereja Katolik, yaitu dengan menggabungkan devosi Mariawi dengan pribadi Yesus Kristus.

Pada dasar keempat ini, dalam pandangan penulis Montfort memperkenalkan Maria yang berbeda dengan Maria dalam sejarah kekristenan. Alkitab mengajarkan bahwa Maria adalah manusia berdosa dan setiap manusia pasti terbatas ruang dan waktu. Roma 5:12 mengatakan "Sebab itu, sama seperti dosa telah masuk ke dalam dunia oleh satu orang, dan oleh dosa itu juga maut, demikianlah maut itu telah menjalar kepada semua orang, karena semua orang telah berbuat dosa." Kemudian dalam 1 Yohanes 2:2 “Dan Ia adalah pendamaian untuk segala

\footnotetext{
63 Setzer merupakan salah satu teolog Katolik dari ordo Saint Montfort Missionaries (SMM).

64 Gabriel Roschini merupakan Imam Katolik asal Italia yang termasuk dalam ordo servants of Mary, dan seorang professor Mariologi.

65 Frank A. Setzer, "The Spiritual Maternity and Saint Louis M. de Montfort," Marian Studies Vol. 3, Article 10, (2015): 198.
} 
dosa kita, dan bukan untuk dosa kita saja, tetapi juga untuk dosa seluruh dunia." Atas dasar ayat-ayat ini, maka disimpulkan bahwa seluruh manusia sudah jatuh ke dalam dosa, termasuk Maria. Maria tetap manusia berdosa yang memiliki kecenderungan untuk melakukan dosa. Dia pun tidak memiliki kehendak 100\% sama dengan Allah dan dia bukanlah pribadi yang memiliki sifat-sifat yang hanya dimiliki Allah. Maria adalah seorang manusia berdosa yang terbatas ruang dan waktu. Ketika Maria meninggalkan bumi pun, roh Maria terbatas sebagai manusia yang sudah diselamatkan. Roh manusia tidak seperti Roh Allah yang sempurna dan tak terbatas. Selain itu, Maria bukanlah pribadi yang menjadi fokus pengajaran gereja. Gereja mengajarkan hal yang utama yaitu Injil dan pribadi Allah Tritunggal. Sehingga apabila di dalam gereja justru ada pribadi yang ditinggikan dan berpotensi melebihi Allah, maka gereja tersebut tidak sesuai dengan pengajaran Firman Tuhan.

Dasar kelima teologi devosi Mariawi menurut Montfort adalah perkataan fiat (persetujuan) Maria kepada malaikat Tuhan (Lukas 1:38). Maria memiliki jasa dan dihormati karena perkataan "Jadilah padaku menurut perkataanmu..." Maria patut dihormati karena pernyataan setuju Maria terhadap panggilan Allah ini. Pernyataan setuju ini dibutuhkan agar rencana Allah dalam inkarnasi Yesus dapat terjadi. Oleh karena persetujuan ini, maka sejarah keselamatan tergenapi mulai dari kehidupan, kematian, kebangkitan Yesus, pencurahan Roh Kudus, berdirinya gereja, anugerah, sakramen, dan perjamuan kudus. Anak Allah menjadi manusia menjadi keselamatan bagi umat manusia di dalam dan melalui Maria. Montfort berkata "It is through Mary that the salvation of the world was begun..." 66 Melalui persetujuan Maria ini, Maria memiliki jasa dalam rencana keselamatan bagi umat manusia.

Menurut penulis, Allah memilih Maria sebagai sarana keselamatan umat manusia bukan dalam konteks bahwa Allah membutuhkan Maria dan tanpa Maria tidak ada jalan keselamatan bagi umat Allah. Keputusan Allah untuk memilih Maria sebagai alat untuk melaksanakan rencana

66 Louis-Marie Grignion De Montfort, Love of the Eternal Wisdom, Point 64. 
keselamatan Allah atas umat-Nya menunjukkan betapa besar anugerah Allah atas diri Maria. Allah memilih Maria sebagai pelayan-Nya. Kalimat fiat dari Maria bukanlah jasa Maria, melainkan anugerah Allah yang menggerakkan Maria untuk taat. Selain itu bukan persetujuan Maria yang membuat Maria memiliki peran yang besar dalam sejarah keselamatan, melainkan karena kedaulatan dan kehendak Allah saja yang mau memakai Maria sebagai pelayan-Nya. Alkitab mengatakan dalam Mazmur 135:6 “TUHAN melakukan apa yang dikehendaki-Nya, di langit dan di bumi, di laut dan di segenap samudera raya;" Maka dari ayat ini manusia dapat melihat bahwa kehendak Allah pasti terjadi. Bukan Maria yang menentukan Yesus Kristus akan lahir sebagai Juruselamat dunia ini, melainkan Allah sendiri. Tuhan berkata bahwa "Aku adalah Alfa dan Omega, Yang Pertama dan Yang Terkemudian, Yang Awal dan Yang Akhir." (Wahyu 22:13). Allah penentu seluruh sejarah kehidupan manusia.

Dasar keenam teologi devosi Mariawi menurut Montfort adalah Maria sebagai sarana anugerah (Mean of grace) dan sarana persembahan (Mean of offering). Sebagai sarana anugerah, dipahami dari sudut pandang bahwa umat manusia memperoleh anugerah hanya berkat perantaraan Maria, setelah Maria memperoleh anugerah di hadapan Allah. ${ }^{67}$ Maria dianggap sebagai jalan menuju Yesus Kristus yang adalah jalan, kebenaran, dan hidup. Maria digambarkan sebagai keran air, pipa yang menyalurkan air dari waduk, leher yang menggerakkan kepala, dan kunci ruang penyimpanan harta kasih Ilahi. 68 Montfort memiliki pandangan seperti ini karena pengaruh dari Santo Bernardus yang berkata "This is the will of God who willed that we should have all things through Mary. If then, we possess any hope or grace or gift of salvation, let us acknowledge that it comes to us through her." 69 Dapat dikatakan bahwa Maria sebagai pengantara manusia kepada Pengantara Allah dan

\footnotetext{
67 Montfort, Bakti Sejati kepada Maria, 44.

68 Ibid., 45.

69 Ibid., 141.
} 
manusia satu-satunya yaitu Yesus Kristus. Kemudian sebagai sarana persembahan, dipahami dari sudut pandang bahwa ketika umat menjalankan devosi kepada Maria ini, maka umat mempersembahkan seluruh karya amal kepada Tuhan Yesus melalui tangan Bunda-Nya yang suci. Karya amal itu dibersihkan dan diperindah oleh Bunda Maria. ${ }^{70}$ Montfort berpandangan bahwa umat tidak pantas untuk mendekati Allah dengan kekuatan sendiri, maka atas dasar ini umat menggunakan perantaraan Bunda Maria di dalam memberikan kemuliaan dan rasa syukur kepada Allah. ${ }^{71}$

Dalam penilaian penulis, berdasarkan Efesus 4:7 “Tetapi kepada kita masing-masing telah dianugerahkan kasih karunia menurut ukuran pemberian Kristus." Allah memberikan anugerah-Nya melalui diri Kristus, tanpa melalui pribadi Maria. Sedangkan mengenai persembahan umat kepada Allah, Efesus 3:12 mengatakan "Di dalam Dia kita beroleh keberanian dan jalan masuk kepada Allah dengan penuh kepercayaan oleh iman kita kepada-Nya." Sumber jalan kepada Allah Bapa adalah melalui Yesus Kristus, dan manusia mempersembahkan segala sesuatu kepada Allah di dalam Kristus yang adalah Pengantara antara manusia berdosa dan Allah yang suci. Di dalam Yohanes 14:6 juga Yesus Kristus sendiri tekankan bahwa "Kata Yesus kepadanya: "Akulah jalan, kebenaran, dan hidup. Tidak ada seorangpun yang datang kepada Bapa, kalau tidak melalui Aku." Maka sumber satu-satunya menerima segala karunia rohani dari Allah Bapa dan kemampuan untuk mempersembahkan sesuatu kepada Allah Bapa adalah di dalam Kristus.

Dasar ketujuh teologi devosi Mariawi menurut Montfort yaitu Maria sebagai ibu rohani. Maria merupakan ibu rohani bagi umat percaya. Di alam roh, Maria berperang melawan Lucifer dan pengikutnya demi melindungi umat Allah. ${ }^{72}$ Dengan demikian, relasi umat percaya terhadap Maria adalah sebagai pengikut dan hambanya.

\footnotetext{
Ibid., 146.

Ibid., 143.

72 Ibid., 52.
} 
Sedangkan menurut penulis, Alkitab tidak mengatakan bahwa roh Maria lebih besar dari roh manusia lainnya. Roh manusia yang telah mati di dalam Kristus, sudah menjadi milik Kristus di surga. Roh manusia ini disempurnakan dalam kekudusan dan masuk dalam kemuliaan (Ibrani 12:23, Lukas 23:43). Alkitab menyatakan bukan roh manusia yang berperang melawan Iblis, melainkan adalah Roh Tuhan sendiri. Segala sesuatu telah ditaklukan-Nya di bawah kaki Kristus (1 Korintus 15:27), dan Yesus sendiri mengatakan "Kepada-Ku telah diberikan segala kuasa di sorga dan di bumi." (Matius 28:18), ini menunjukkan bahwa Kristus yang melindungi umat Allah dan membawa umat Allah menuju Allah Bapa.

Penulis berpandangan bahwa teologi devosi Mariawi yang diajarkan Montfort adalah sebuah pemikiran baru pada zamannya yang menyegarkan kembali doktrin Mariologi dalam sejarah Gereja Katolik. Montfort memiliki maksud yang baik yaitu untuk memperkuat iman jemaat melalui penggalian doktrin Mariologi. Akan tetapi, dengan tujuh dasar yang sudah disebutkan, hal tersebut membuat pribadi Maria dipahami sebagai pribadi yang ilahi yang sangat sentral dalam devosi umat dan teologi Katolik. Jika Yesus menjelma menjadi manusia disebut inkarnasi, maka ajaran Montfort secara tersirat membuat Maria yang adalah manusia berdosa menjadi memiliki roh dan kuasa ilahi/ inspiritualisasi ${ }^{\mathrm{7} 3}$.

\section{Kesimpulan dan Saran}

Tujuh dasar teologi devosi Mariawi menurut Montfort ini memberikan pengaruh yang sangat signifikan pada teologi dan spiritualitas Katolik. Salah satu pengaruh terbesar dari karya Montfort adalah pengaruhnya kepada Paus Paulus VI dan Paus Yohanes Paulus II. Paus Paulus VI mengeluarkan Ensiklik Marialis Cultus (Marian Devotion) pada tahun 1974 yang berisi tata cara devosi kepada Maria. Paus Yohanes

\footnotetext{
73 Istilah penulis untuk menggambarkan keilahian yang ditambahkan kepada Maria. Antonim dari inkarnasi.
} 
Paulus II mengeluarkan Ensiklik Rosarium Virginis Mariae (On the Most Holy Rosary) pada tahun 2002, mengenai doa Rosario bersama Maria untuk memiliki kesatuan bersama Kristus. Pengaruh berdampak pada Paus, otomatis akan memengaruhi teologi Katolik dan umat Katolik. Pengaruh yang terjadi pada teologi Katolik dan umat Katolik, otomatis akan memengaruhi spiritualitas Katolik itu sendiri. Apa yang diajarkan oleh Montfort memengaruhi spiritualitas Katolik sehingga dalam Katolik muncul ordo Montfortian. Ordo ini mempelajari kehidupan dan ajaran Montfort serta membentuk tarekat-tarekat untuk menjalankan pelayanan apostoliknya. Tiga kongregasi yang muncul dalam ordo Montfortian bernama Company of Mary, Daughter of Wisdom, dan Brothers of Saint Gabriel.

Penulis menyimpulkan bahwa pandangan Katolik tentang Maria pada dasarnya konsisten dengan 3 pilar sumber iman mereka. Katolik tidak menganut Sola Scriptura seperti yang dianut teologi Reformed. Oleh karena itu Katolik dapat terus mengembangkan dogma-dogma tentang Maria berdasarkan sumber iman yang dipercayai. Kemudian karya yang dikerjakan Montfort mengenai devosi kepada Maria menghadirkan warna baru di dalam teori, cara pandang, devosi, spiritualitas Katolik, dan iman umat kepada Maria. Maria menjadi objek iman yang dipercaya dan dinikmati oleh umat Katolik. Keunikan Montfort adalah mengaitkan devosi Mariawi dalam konteks tujuan akhir penghormatan kepada Yesus Kristus.

Penulis memberikan saran berkaitan dengan cara pandang orang Kristen terhadap Maria dan relasi umat Kristen dengan umat Katolik. Pertama, sejalan dengan cara pandang yang diberikan teolog-teolog Reformed, umat Kristen tidak boleh mengabaikan pribadi Maria yang diajarkan dalam Alkitab. Maria merupakan salah satu model kehidupan Kristen yang begitu takut akan Tuhan dan memiliki teladan ketaatan kepada panggilan Allah dalam rencana keselamatan umat Allah. Umat Kristen perlu mempelajari lebih banyak kebajikan yang dimiliki Maria. Kedua, melihat budaya kehidupan Alkitab yang patriakal, umat Kristen 
perlu menyadari bahwa umat Kristen kekurangan pengajaran mengenai figur wanita yang takut akan Allah. Oleh karena itu, khususnya bagi wanita Kristen, dapat belajar secara mendalam dan meneladani tentang kebajikan-kebajikan Maria. Misalnya seperti kerendahan hati Maria dalam menerima panggilan Tuhan sebagai ibu Yesus, keberaniannya menemani Yesus seumur hidup-Nya sampai di bawah kayu salib, dan kebijaksanaan Maria dalam mendidik dan memahami Yesus Kristus di dunia. Ketiga, ketika umat Kristen mempelajari pribadi Maria dan pekerjaan Tuhan dalam diri Maria, umat Kristen tidak boleh berelasi dan berdoa kepada pribadi Maria. Umat Kristen harus menghormati Maria, tetapi bukan dengan berelasi dan berdoa kepadanya, melainkan memberi penghormatan kepada Maria yaitu dengan taat dan menjalankan perintah dari Tuhan Yesus Kristus. Melalui menaati Yesus Kristus ini, umat Kristen dapat memberi penghormatan kepada Maria yang pernah dipakai Tuhan sebagai hamba-Nya. 